8 the 5 (12) SEP 182000

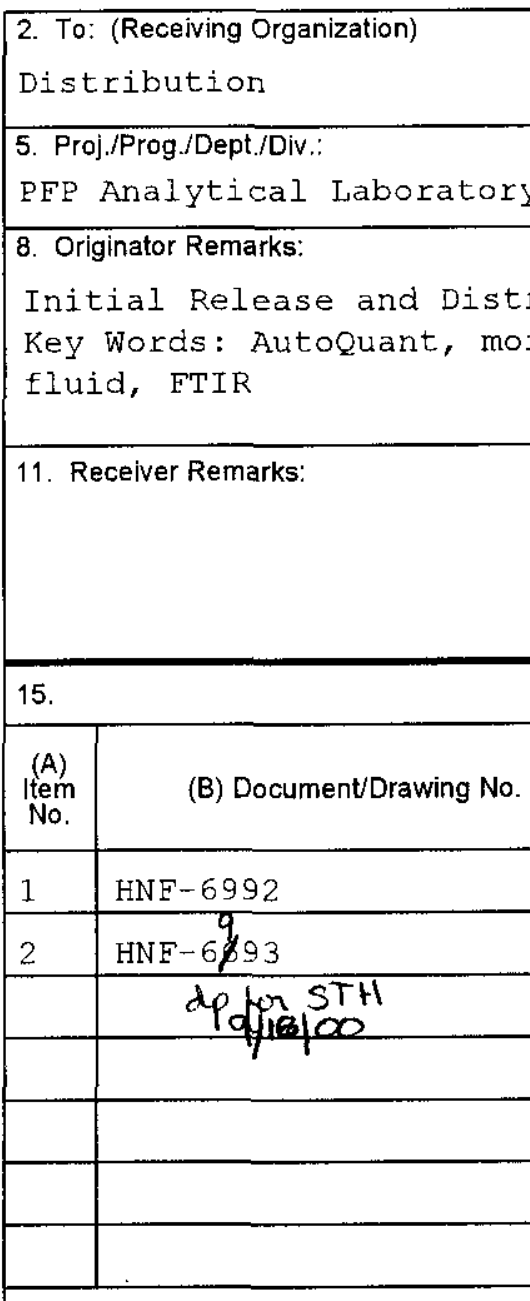

16.
11A. Design Baseline Document? $\bigotimes$ Yes $\square$ No

3. From: (Originating Organization)
Plutonium Finishing Plant
$\begin{aligned} & \text { 6. Design Authority/Design Agent/Cog. Engr.: } \\ & \text { ST Hurlbut }\end{aligned}$

ribution

water, analysis, supercritical

.

4. Related EDT No.:

N/A

7. Purchase Order No:

$\mathrm{N} / \mathrm{A}$

9. Equip./Component No.:

$\mathrm{N} / \mathrm{A}$

10. System/Bldg./Facility:

PEP

12. Major Assm. Dwg. No.:

$\mathrm{N} / \mathrm{A}$

13. Permit/Permit Application No.:

$\mathrm{N} / \mathrm{A}$

14. Required Response Date:

$\mathrm{N} / \mathrm{A}$

\begin{tabular}{|c|c|c|c|}
\hline$(F)$ & $(G)$ & $(H)$ & $(l)$ \\
\hline $\begin{array}{c}\text { Approval } \\
\text { Desig- } \\
\text { nator }\end{array}$ & $\begin{array}{c}\text { Reason } \\
\text { for Trans- } \\
\text { mittal }\end{array}$ & $\begin{array}{c}\text { Origi- } \\
\text { nator } \\
\text { Dispo- } \\
\text { stion }\end{array}$ & $\begin{array}{c}\text { Receiv- } \\
\text { er } \\
\text { Dispo- } \\
\text { sition }\end{array}$ \\
\hline $\mathrm{Q}$ & 2 & & \\
\hline $\mathrm{Q}$ & 2 & & \\
\hline & & & \\
\hline & & & \\
\hline & & & \\
\hline
\end{tabular}

\begin{tabular}{|c|c|c|c|c|}
\hline Approval Designator (F) & \multicolumn{2}{|r|}{ Reason for Transmittal (G) } & \multicolumn{2}{|c|}{ Disposition (H) \& (I) } \\
\hline $\begin{array}{l}E, S, Q, D O R \text { N/A } \\
\text { (See WHC-CM-3-5, } \\
\text { Sec. 12.7) }\end{array}$ & $\begin{array}{l}\text { 1. Approval } \\
\text { 2. Release } \\
\text { 3. Information }\end{array}$ & $\begin{array}{l}\text { 4. Review } \\
\text { 5. Post-Review } \\
\text { 6. Dist. (Receipt Acknow. Required) }\end{array}$ & $\begin{array}{l}\text { 1. Approved } \\
\text { 2. Approved w/comment } \\
\text { 3. Disapproved w/comment }\end{array}$ & $\begin{array}{l}\text { 4. Revjewed no/comment } \\
\text { 5. Reviewed w/comment } \\
\text { 6. Receipt acknowledged }\end{array}$ \\
\hline
\end{tabular}

17.

BD-7400-172-2 (10/97)

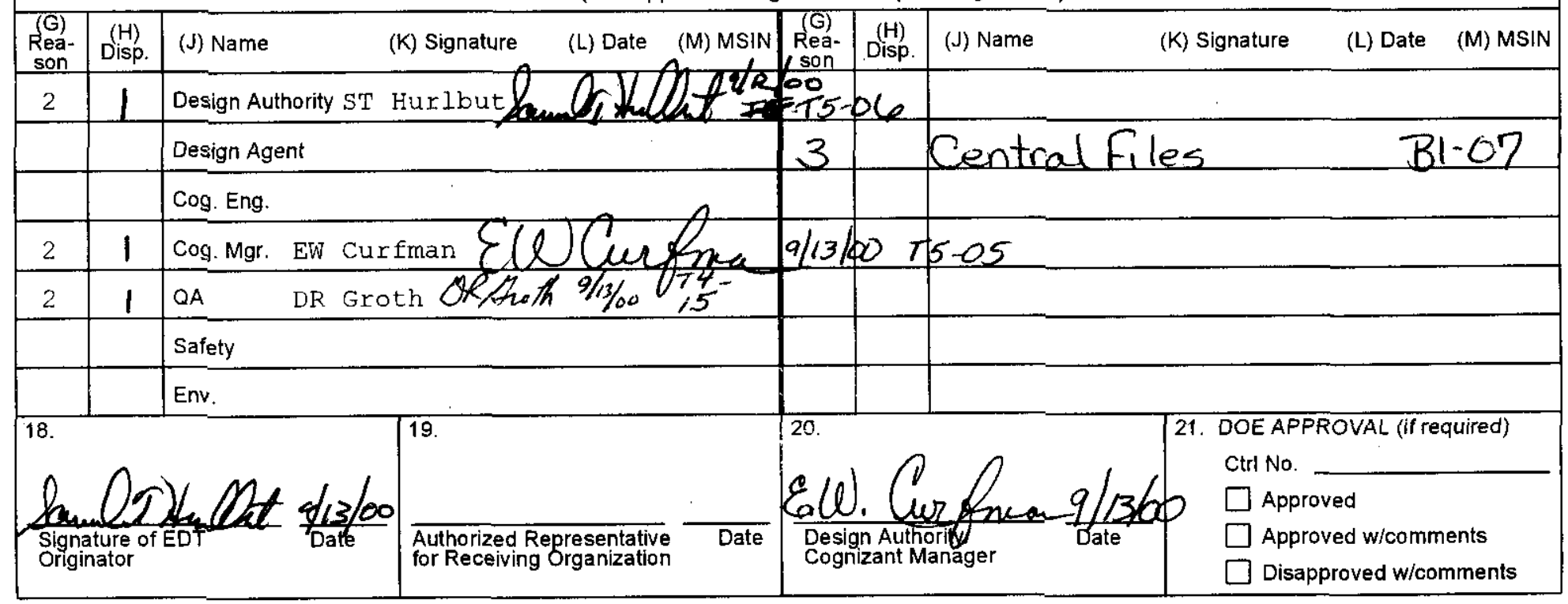

KEY

DATA TRANSMITTED

\begin{tabular}{c|c|c}
$\begin{array}{c}\text { (C) Sheet } \\
\text { No. }\end{array}$ & (D) Rev. \\
No. & (E) Title or Description of Data Transmitted
\end{tabular} 0 Software Mgmt, Req, Design 0 Software Test Plan (See Approval Designator for required signatures) 
HNF-6993

Revision 0

\section{AutoQuant 3, version 3.11, MIDAC Corporation Computer Software Test Plan}

Prepared for the U.S. Department of Energy

Assistant Secretary for Environmental Management

Project Hanford Management Contractor for the

U.S. Department of Energy under Contract DE-AC06-96RL13200

Fluor Hanford

P.O. Box 1000

Richland, Washington 


\title{
AutoQuant 3, version 3.11, MIDAC Corporation \\ Computer Software Test Plan
}

\author{
S. T. Hurlbut
}

Fluor Hanford

Date Published

September 2000

Prepared for the U.S. Department of Energy

Assistant Secretary for Environmental Management

Project Hanford Management Contractor for the

U.S. Department of Energy under Contract DE-AC06-96RL13200

\section{Fluor Hanford}

P.O. Box 1000

Richland, Washington
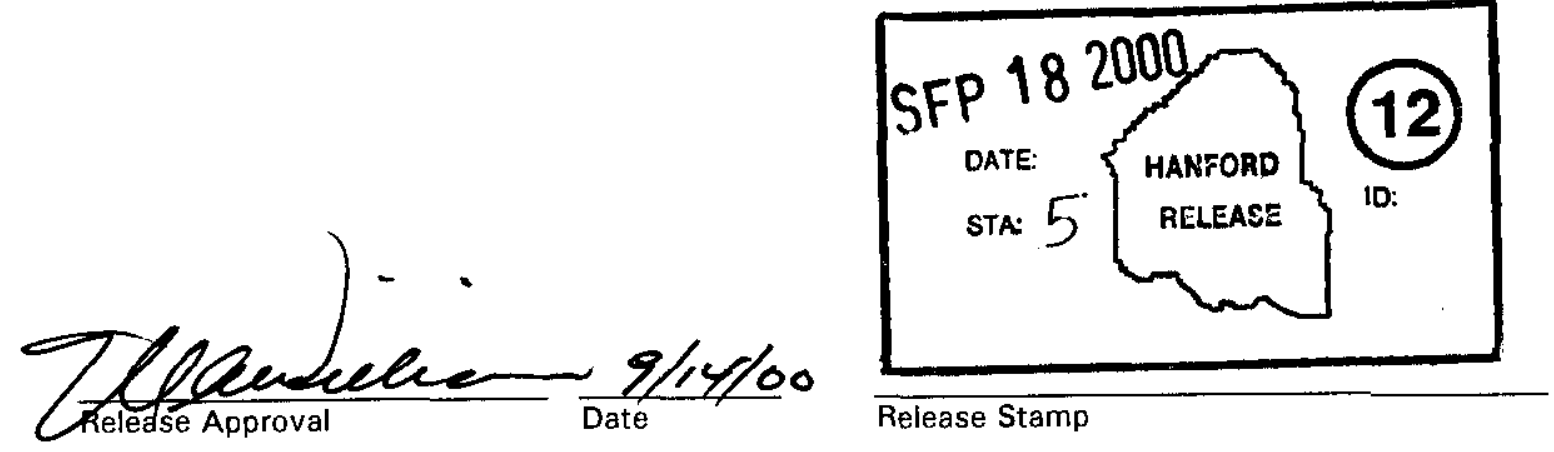
HNF-6993

Revision 0

TRADEMARK DISCLAMMER

Reference herein to any specific commercial product, process,

or service by trade name, trademark, manufacturer, or

otherwise, does not necessarily constitute or imply its

endorsement, recommendation, or favoring by the United

States Government or any agency thereof or its contractors or

subcontractors.

This report has been reproduced from the best avallable copy.

Printed in the United States of America

Total Pages: 15

- AutoQuant is a registered trademark of ADAC Laboratories. 


\section{AutoQuant 3, version 3.11, MIDAC Corporation Computer Software Test Plan}

$\frac{G \cdot(b) \text { lerfman }}{\text { E. W. Curfman, Fluor Habtord, Inc. }} \frac{9 / 12 / 00}{\text { Date }}$

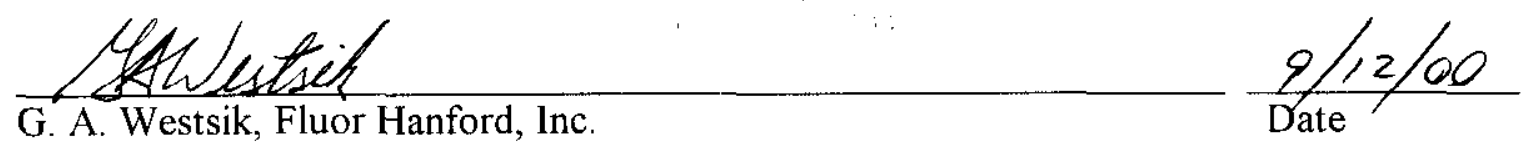

Prepared by

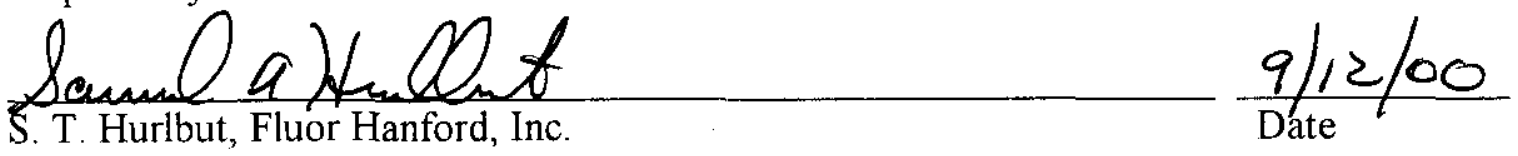




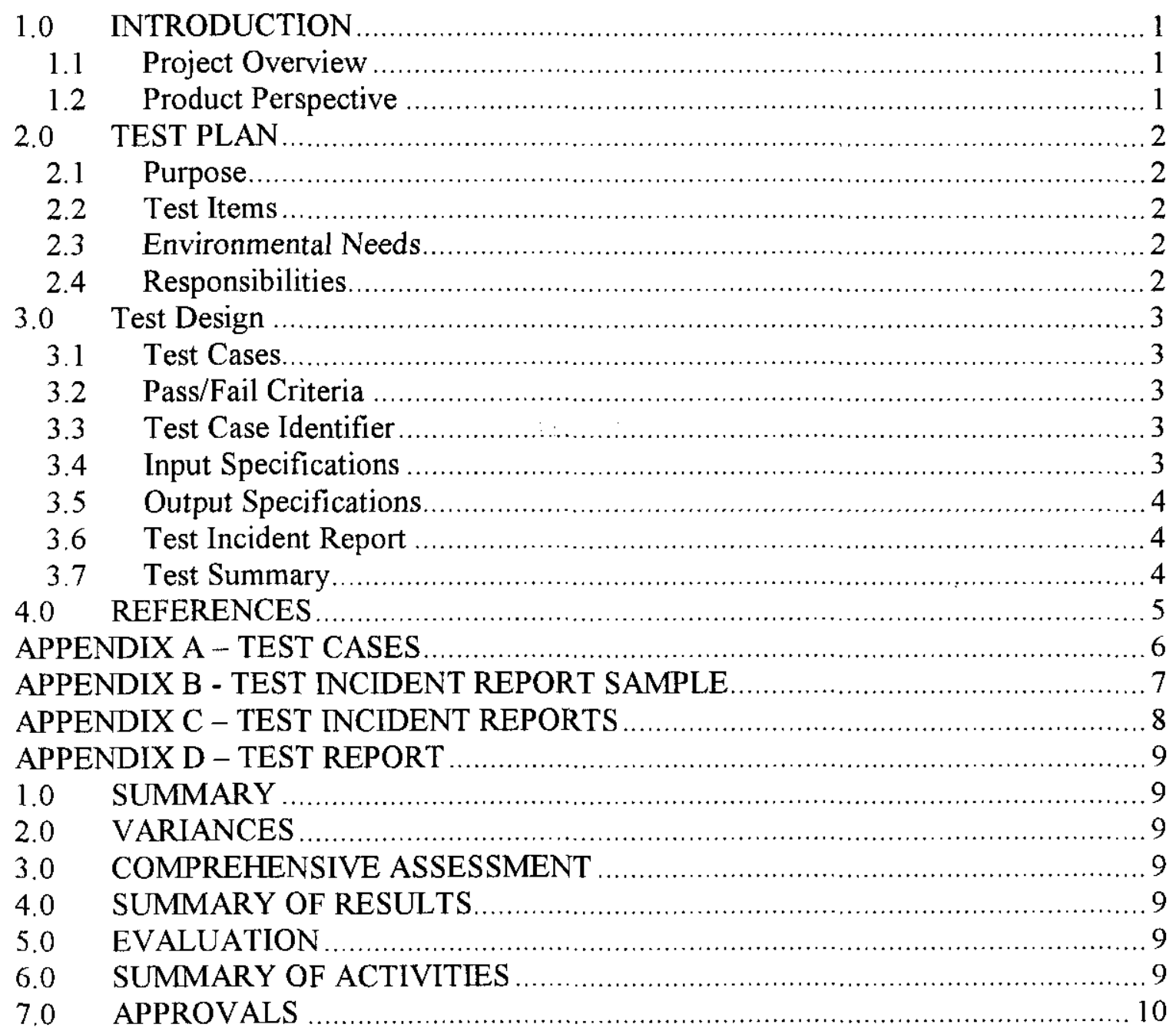




\section{$1.0 \quad$ INTRODUCTION}

\subsection{Project Overview}

AutoQuant is a vendor software product used to control the Fourier transform infrared spectrometer (FTIR) used as a detector for the supercritical fluid extraction system (SFE). This product acts as the operating environment for the FTIR. AutoQuant will be used in conjunction with procedure ZA-565-301, "Determination of Moisture by Supercritical Fluid Extraction and Infrared Detection."

\subsection{Product Perspective}

AutoQuant is a proprietary program provided by the MIDAC Corporation, vendor of the FTIR instrument. 


\subsection{TEST PLAN}

\subsection{Purpose}

This test plan will be performed in conjunction with or prior to HNF-6936, "HA-53 Supercritical Fluid Extraction System Acceptance Test Plan", to operate the Fourier transform infrared spectrophotometer (FTIR) and to perform analyses for water. The test will ensure that the software can be installed properly, will operate the FTIR correctly and will generate a text file with analytical data.

\subsection{Test Items}

This test document is specifically written to test the installation and operation of the AutoQuant software in connection to the MIDAC FTIR.

\subsection{Environmental Needs}

AutoQuant will be installed on a computer meeting the hardware requirements in the MIDAC User's Guide including the MIDAC supplied interface board. The computer will be connected to the MIDAC FTIR.

\subsection{Responsibilities}

The scientist responsible for the analytical procedure, ZA-565-301, shall be responsible for preparing the test and resolving any test-related issues. The test shall be witnessed by a PFPAL team leader/manager. 


\subsection{Test Design}

\subsection{Test Cases}

Test cases and their test items will be executed in the order they are numbered. Results of the testing process, including visually observable results (error message generated, aborts, and requests for operation action) and notes on the successful execution of the test will be documented in each test case; Pass/Fail notes will be indicated on the test cases. Test cases are included in Appendix A of this document.

Test incidents, with the disposition of any anomalies discovered during testing, will be documented. Test problems/deficiencies/defects need to be noted on a test incident report, indicating the specific item where the problem occurred. Test incidents are integral to the test cases and will be kept with the record copies of the test cases. A sample test incident report is included in Appendix B. Actual test incident reports will be included in Appendix C.

At the successful completion of all test cases, a Test Summary report will be prepared. The Test Summary Report is included in Appendix D.

\subsection{Pass/Fail Criteria}

Acceptance criteria state the conditions that must be satisfied by the system or product before the user formally accepts the system. If a test case achieves all of its requirements, it is considered a PASS. If a test case does not achieve all of its requirements, it is considered a FAIL and must be corrected and retested. If the test produces a result that is not desirable by the user or the user's management and it meets the requirements detailed in the test case, a decision must be made to either change the requirement and retest, or PASS the test.

\subsection{Test Case Identifier}

All test cases will be uniquely identified by a test case number. Each test item will also be numbered to provide a means of identifying anomalies.

\subsection{Input Specifications}

Test data will be developed or provided to thoroughly test all areas of the system. Where possible, this data will be identified in such a way that the correct outcome is known in advance. Effectiveness of the data will be ensured through joint participation by user personnel. Transactions that are specifically designed to check internal controls and decision logic will be included. Examples of invalid, abnormal, and incomplete transactions will be included in the test data. These transactions will be checked to verify that they work properly and give the appropriate responses to improper conditions. 


\subsection{Output Specifications}

All elements within the system will meet or exceed the following requirements, as stated in the test cases.

- File data will be of documented length and type.

- Screens will be formatted and display/update data as documented.

- Reports will present data consistent with stated requirements.

\subsection{Test Incident Report}

Test incidents will be reported using the Test Incident report (See Appendix B). Required information is as follows:

- Test Case and test item numbers

- Date encountered

- Expected results

- Actual results

- Tester name

- Witness (if required)

These forms will be followed up with the users, users' manager and responsible scientist to determine course of action, which may include correction to the software or change to the requirement.

\subsection{Test Summary}

At the completion of the testing process, a test summary report will be completed (Appendix C). This report will evaluate and summarize the test results including the following:

- Identify the system and the items tested, indicating their revision identification.

- Indicate the environment in which the testing activities took place.

- State whether or not the system is ready for operation.

- Supply references to the following documentation if they exist: test plan, test design, test cases, and test incident report.

This Summary will also include a Test Verification Sheet to be signed by the appropriate persons to indicate the final validation and acceptance of the system. 


\subsection{REFERENCES}

AutoQuant User's Guide, MIDAC Corporation, Irvine, CA

ZA-565-301, Determination of Moisture by Supercritical Fluid Extraction and Infrared Detection, Fluor Hanford, Inc., Richland, WA

HNF-6936, HA-53 Supercritical Fluid Extraction System Acceptance Test Plan, Fluor Hanford, Inc., Richland, WA 
APPENDIX A - TEST CASES

\begin{tabular}{|c|c|c|c|c|}
\hline $\begin{array}{l}\text { TEST } \\
\text { STEP }\end{array}$ & ACTION & EXPECTED RESULT & $\begin{array}{l}\text { PASS/ } \\
\text { FAIL }\end{array}$ & $\begin{array}{l}\text { P/F ON } \\
\text { RETEST }\end{array}$ \\
\hline 1 & $\begin{array}{l}\text { Install software per vendor } \\
\text { instructions. }\end{array}$ & The software installs. & & \\
\hline 2. & Create a method for water. & $\begin{array}{l}\text { Method is created without } \\
\text { incident. }\end{array}$ & & \\
\hline 3. & $\begin{array}{l}\text { Perform Standard } \\
\text { Collection }\end{array}$ & $\begin{array}{l}\text { Spectral data will be } \\
\text { collected. }\end{array}$ & & \\
\hline 4. & Save data in a text file. & Text file will be created. & & \\
\hline 5 & $\begin{array}{l}\text { Create a full calibration } \\
\text { curve. }\end{array}$ & $\begin{array}{l}\text { Step } 9.9 \text { of HNF-6936 is } \\
\text { completed successfully. }\end{array}$ & & \\
\hline
\end{tabular}

Tester Initials

(this should appear on each test case page) 


\section{APPENDIX B - TEST INCIDENT REPORT SAMPLE}

\section{Incident Identification}

Incident No.

Date

Test Case No.

Item No.

Description of Incident: (Identify expected results and actual results)

\section{Determination}

[ ]Fix Before Implementation [ ]Fix After Implementation [ ]Change in Scope

Action Taken:

Impact On Previous or Following Tests:

Incident Documented:

Test Performer

Date

Test Witness

Date

Test Administrator

Date

Correction Verified:

Test Performer

Date

Test Witness

Date

Test Administrator

Date 


\section{APPENDIX C - TEST INCIDENT REPORTS}

Incident reports, if any will be generated at the conclusion of testing. 


\subsection{SUMMARY}

Evaluate and summarize the test results. Identify the system and the items tested, indicating their revision identification. Indicate the environment in which the testing activities took place. State whether or not the system is ready for operation. Supply references to the following documentation if they exist: test plan, test design, test procedures, test item transmittal reports, test logs, and test incident report.

\subsection{VARIANCES}

Report any variances of the test items from their design specifications. Indicate any variances from the test plan, test designs, or test procedures during the testing. Specify the reason for each variance.

\subsection{COMPREHENSIVE ASSESSMENT}

Evaluate the comprehensiveness of the testing process against the acceptance criteria. Identify features or feature combinations that were not sufficiently tested, and explain the reasons.

\subsection{SUMMARY OF RESULTS}

Summarize the results of testing. Identify all resolved incidents, and summarize their resolutions. Identify all unresolved incidents and the impact on placing the system into operation.

\subsection{EVALUATION}

Provide an overall evaluation of each test item, based upon the test results. Provide an estimate of failure risk.

\subsection{SUMMARY OF ACTIVITIES}

Summarize the major testing activities and events. Summarize resource consumption data, for example, total staffing level, total machine time, and total elapsed time used for each of the major testing activities. 
HNF-6993

09/13/2000

\subsection{APPROVALS}

Revision 0

Specify the names and titles of all persons who must approve this report. Provide space for signatures and dates.

Date

Date

Date 